\title{
The Determinants of Share Repurchases in Europe
}

\author{
Dimitris Andriosopoulos ${ }^{\mathrm{a}, \mathrm{b}}$ and Hafiz Hoque ${ }^{\mathrm{a}}$ \\ ${ }^{a}$ Swansea University, Singleton Park, SA2 8PP, Swansea, Wales, United Kingdom. \\ ${ }^{b}$ Corresponding author: e-mail: D.Andriosoopoulos@ @wansea.ac.uk; tel.:+44(0) 179229 \\ 5180 .
}

\section{Published in the International Review of Financial Analysis}

\begin{abstract}
In this paper, we assess which firm-characteristics are associated with a firm's decision to announce a share repurchase programme in a cross-country framework. In the models, we incorporate firm-specific financial characteristics and measures of share price performance. We find that size, cash dividends, and ownership concentration consistently have a significant impact on share repurchase announcements in all three countries under study. However, the share price performance does not explain the decision to announce a share repurchase. The robustness of the proposed models is investigated across different dimensions of sample-matching methods and with a boot-strap technique. Finally, we construct a number of models with a robust predictive ability of a firm's likelihood to announce a share repurchase.
\end{abstract}

Key words: Share repurchases, determinants, information asymmetry, logit model, boot-strap

JEL Classification: G14, G32, G34, G35

$\uparrow$ We thank an anonymous reviewer, Aneel Keswani, Meziane Lasfer, Dylan Thomas, Steven Young, Moqi Xu and the participants of the 2010 Trans-Atlantic Doctoral Conference of London Business School, the 2010 EURO working group on efficiency \& productivity analysis in Crete, Greece, and the finance seminars of Cass Business School for their helpful comments. Finally, we thank Nikos Nomikos for providing a routine for the bootstrap simulation. 


\section{Introduction}

Share repurchases have become a common way of returning cash to shareholders in the US (Julio and Ikenberry, 2004), but it was only during the late 1990s that share repurchases gained an increasing popularity in Europe (v.Eije and Megginson, 2008). This is because share repurchases were virtually illegal until then, when a change in regulations allowed firms to conduct open market share repurchases. ${ }^{1}$ Since open market repurchase announcements are not firm commitments, managers may make such announcements in order to mislead markets and "artificially" increase their firm's share price by announcing their intention to buy back shares (Babenko, 2010). Hence, it becomes imperative to have a clear understanding of the management's motives for making such announcements. In this paper, we analyse the determinants of open market share repurchases in the UK, Germany, and France with a unique hand-collected data.

Jain et al. (2009) investigate what drives a firm's choice to either initiate dividends or repurchase shares following their initial public offering (IPO) and find that the drivers between the two payout methods are fundamentally different. However, Jain et al. (2009) limit their study to only those firms moving from a highgrowth to a low-growth stage since these firms are able to cover their investment opportunities and still enjoy excess cash. An additional limitation in Jain et al. (2009) is that buybacks and dividends are treated as perfect substitutes despite the controversial empirical evidence on the matter (e.g., Grullon and Michaely, 2002; De Angelo et al., 2000; Jagannathan et al., 2000; Dittmar, 2000; Mitchell and

\footnotetext{
${ }^{1}$ In France, open market share repurchases can be authorized by the firm's shareholders for up to the limit of $10 \%$ of a firm's capital since July 2, 1998. This authorisation can extend for a maximum period of 18 months, and the shares repurchased can be cancelled or kept as treasury stock (Ginglinger and Hamon, 2007). In Germany, prior to the legislation passed on May 1, 1998, share repurchases were illegal as they were perceived to be a prohibited repayment of capital; they are permitted only in exceptional circumstances and in individual cases. In contrast, in the UK, share repurchases have been legal since 1981. After the ambiguous tax treatment in the earlier years, they became popular.
} 
Dharmawan, 2007; Denis and Osobov, 2008). Similarly, Chay and Suh (2009) find that mature firms with low cash flow uncertainty are more likely to pay dividends supporting the life-cycle theory of dividends (De Angelo et al., 2006; Denis and Osobov, 2008). We do not take the substitutability of dividends by repurchases as de facto since the interrelationship of dividends and repurchases is affected by tax, corporate, and institutional factors (Alzahrani and Lasfer, 2012) and since the decision to announce a dividend payment will be based on a number of additional factors such as firms' long-term performance, growth and earnings sustainability (Skinner, 2008), the life-cycle of dividends (Denis and Osobov, 2008), and their inherent 'stickiness'. Rather, we examine the firm-level characteristics that are associated with the decision whether to announce a share repurchase programme or not.

Guay and Harford (2000) and Barth and Kasznik (1999) find (respectively) in the US that less permanent cash flows, intangible assets and idle cash increase the likelihood of a share repurchase. However, these studies focus only on the impact of cash flows without accounting for other potential drivers that can have a significant impact on the share repurchase announcement. Mitchell and Dharmawan (2007) address this issue by employing data from the Australian market and find that undervaluation, ownership concentration, free cash flow, and excess debt capacity are the most influential factors. Therefore, in this study, we are considering the option of either announcing the intention to repurchase shares or to not make such an announcement at all across a set of European countries, hence, extending previous single-country evidence.

The overwhelming majority of the findings reported in the existing literature are derived from single-country analyses and are mostly focused on the US market. The regulations that apply on share buybacks differ significantly across countries, 
rendering it precarious to draw the same inferences between countries regarding share buybacks. In particular, unlike the US, where repurchases are approved only by the board of directors with no timing, price, and volume restrictions, EU legislation stipulates that: firms need to acquire approval from the shareholders at the shareholder meeting, the approval is valid for a maximum of 18 months, the proportion of shares to repurchase is limited to $10 \%$, the repurchase price range to be paid is disclosed, and repurchases should be made out of distributable profits only. But, even within the EU, regulations differ. For instance, UK firms can buy back up to $15 \%$, and it is only since 2003 that repurchase shares can be kept as Treasury Shares. Moreover, each EU country can use its own discretion to impose rules in addition to the rules established by the EU Directive.

Brounen et al. (2004) find that in the UK, managers are more shareholderoriented and concerned with shareholder wealth maximisation as opposed to Germany and France, where shareholders are considered less important and managers focus more on efficiency and continuity; however, they find no differences across countries on setting the capital structure. Rosenthal and Sinha (2011) argue that share buybacks may not necessarily lead to shareholder wealth maximisation and that countries with weak investor protection are less prone to value maximisation when setting their payout policies. Alzahrani and Lasfer (2012) find that both taxation and governance frameworks have as strong impact on corporate payouts. In particular, they find that in strong investor protection countries (e.g., the UK), when the agency costs are lower than the tax costs of dividends, investors prefer to receive fewer dividends, which can be substitutive by generally more tax-efficient share buybacks. On the other hand, countries with weak investor protection (e.g., France and Germany) managers do not consider their investor's taxation when setting payout policies. 
As in Agrawal (2012), who finds that stringent regulations empower investors to exert more pressure on management for paying cash dividends, we address the question of whether payout policies are affected by regulatory and institutional frameworks by performing a cross-country analysis distinguished by a wide diversity in terms of institutional, regulatory, and tax settings (Alzahrani and Lasfer, 2012; La Porta et al., 2000; v.Eije and Megginson, 2008), corporate governance frameworks, shareholder protection, managerial attitudes towards shareholder wealth maximisation, firm growth, and sustainability (La Porta et al., 1997, 1999, 2000; Brounen et al., 2004; Morck et al., 2005). Different managerial attitudes and levels of ownership concentration are likely to have varying impacts on management's decision to announce a share repurchase. Although there is some evidence in the existing literature on share repurchases in Europe, there is a gap in terms of analysing the determinants of what drives firms to announce a share repurchase programme. Finally, we contribute to the literature by identifying across countries which factors consistently drive across countries the decision to make a share buyback announcement and by providing fresh European evidence enhancing our understanding of payout practices across countries as argued by De Angelo and De Angelo (2007).

In order to identify which characteristics drive a firm's decision to announce a share repurchase programme, we identify 970 open market buyback announcements in the United Kingdom, France, and Germany. The results show that, consistently in all three countries, large firms that are widely held and pay cash dividends are more likely to announce their intention to repurchase their shares in the open market. Furthermore, we find it is only in the UK that the excess cash flow is positively related to the likelihood of announcing a share repurchase. We find evidence that the 
differences in country characteristics are important in making buyback announcements. In particular, in the UK and Germany, dividends and share buybacks seem to be complements rather than substitutes (Mitchell and Dharmawan, 2007), whereas in France, share buybacks substitute dividends as shown by the negative coefficient of cash dividends consistent with Grullon and Michaely (2002) and Skinner (2008). In addition, we find that the tax advantage of share repurchases over cash dividends has a significant influence on managers' decisions to make buyback announcements. In the unmatched samples in the UK and Germany, the tax differential has a positive and significant impact on the likelihood of a buyback announcement. This suggests that, in France, managers are not concerned with catering to their shareholders' tax considerations. This is consistent with Brounen et al. (2004), who find that managers are less shareholder-oriented, and is in line with Alzahrani and Lasfer (2012), who find that the impact of tax consideration on payouts is relatively weak as opposed to countries with strong investor protection, such as the UK. Finally, we construct a number of logit models, which have a strong predictive ability of more than $70 \%$, especially in the UK and France, by employing only publicly available firm-specific characteristics.

The remainder of this paper is organised as follows. Section 2 discusses the current literature and the factors that can potentially influence share repurchase announcements. Section 3 presents the data and provides an overview of the descriptive statistics and methodology. Section 4 discusses the empirical results, and Section 5 concludes.

\section{Potential drivers of open market share repurchase announcements}

When a company's existing capital exceeds its potential investment opportunities, the firm can either retain the excess cash or distribute it back to its 
shareholders in order to reduce the potential agency costs (Easterbrook, 1984; Jensen, 1986), typically via dividends or share repurchases. One of the advantages of share buybacks is that they are a flexible form of cash distribution since they are not firm commitments, contrary to dividends, which are also 'sticky' since the market penalises firms that reduce or omit their dividend payment (Grullon et al., 2002; Amihud and Li, 2006; Allen and Michaely, 2003).

Grullon and Michaely (2004) find a positive relationship between the reduction of free cash flows and the market reaction to share buybacks. Moreover, share buybacks occur from less permanent cash flows (Guay and Harford, 2000), and firms are more likely to repurchase shares when they hold high levels of excess cash (Dittmar, 2000; Mitchell and Dharmawan, 2007). We expect the presence of excess cash to increase the propensity to repurchase shares. As in Dittmar (2000), we use as a proxy for excess cash the ratio of net operating income before taxes and depreciation to total assets $(C F)$ at the year-end prior to the repurchase announcement. As an alternative proxy, following Opler and Titman (1993), we construct a dummy variable $(D F C F)$ that takes the value of one for firms that have simultaneously low Tobin's $q$ (lower than the median $q$ of a firm's respective industry for each respective year) and high cash flow (higher than the median cash flow of the respective industry for each year) and the value of zero otherwise. ${ }^{2}$

Firms with excess cash flows in the absence of investment opportunities are more likely to experience high agency costs incurred between minority and controlling shareholders (Shleifer and Vishny, 1997). When management holds the majority of a firm's shares and the firm conducts a share repurchase, in effect management pays with its own wealth (Peyer and Vermaelen, 2005), whereas when

\footnotetext{
${ }^{2}$ We replicate the logit estimations with the interaction variable FCF, which is the interaction variable of CF and MKBK (Opler and Titman, 1993; Mitchell and Dharmawan, 2007) and the results remain unaltered.
} 
the costs of reducing agency costs are low, then it is to the management's benefit to repurchase shares and reduce the ownership dispersion (Jensen and Meckling, 1976). For instance, Rajan and Zingales (1995) argue that the presence of large shareholders may reduce the agency costs, thereby decreasing the propensity for debt, when on the other hand, if the large shareholders are banks, they may be keen on increasing the firm's borrowing from the banks. Since controlling shareholders can influence the company's decisions to their benefit at the expense of minority shareholders (La Porta et al., 2000), share repurchases can act as a control for reducing agency costs.

The results reported in Fenn and Liang (2001) suggest that share repurchases are used for reducing potential agency costs, contrary to Jagannathan and Stephens (2003), who find that firms that repurchase most frequently have the lowest level of managerial ownership, as in Shleifer and Vishny (1997) and Mitchell and Dharmawan (2007). Moreover, the lower the ownership concentration, the higher the payouts firms make, both via dividends and buybacks (Bartram et al., 2009), and firms with low investment opportunities and high overinvestment risk display an incrementally positive relationship between insider ownership and share buybacks (Oswald and Young, 2008). Therefore, we assess whether ownership concentration can influence share buybacks by using the percentage of closely held shares ${ }^{3}$ divided by the number of total common shares outstanding (OWN CON) (Mitchell and Dharmawan, 2007; Bartram et al., 2009).

\footnotetext{
${ }^{3}$ The variable Closely Held Shares is taken from Worldscope and represents the following: shares held by insiders; shares held by officers, directors, and their immediate families; shares held in trust; shares of the company held by any other corporation (except shares held in a fiduciary capacity by banks or other financial institutions); shares held by pension/benefit plans; and shares held by individuals who hold $5 \%$ or more of the outstanding shares. It excludes: shares under option exercisable within sixty days; shares held in a fiduciary capacity; shares held by insurance companies; and preferred stock or debentures that are convertible into common shares. Even though this proxy has its limitations (e.g., it does not distinguish between shareholder types) it serves as a reliable indication of the impact that ownership concentration can have on payout decisions, such as share repurchases.
} 
Previous studies report evidence that companies are more likely to repurchase stock if their respective leverage ratios are below their targets (Mitchell and Dharmawan, 2007; Dittmar, 2000). Moreover, a share repurchase reflects the management's preference to use debt instead of equity in order to move closer to an optimal leverage ratio (Bagwell and Shoven, 1988; Hovakimian et. al., 2001). Supporting this argument, Jagannathan and Stephens (2003) find that firms with low debt tend to repurchase their shares more frequently. Therefore, we expect to find that the decision to announce a share repurchase will be motivated by the firm's current leverage ratio and a negative relationship between debt and the decision to repurchase. Following Dittmar (2000) and Grullon and Michaely (2002), we employ the ratio of total debt to total assets $(L V G)$ at the year-end prior to the buyback announcement as a proxy for leverage.

A wealth of studies find evidence that firms repurchase their shares to signal their undervaluation (e.g., Ikenberry et al., 1995; De Cesari et al., 2011; Ikenberry et al., 2000; Lasfer, 2005; Ginglinger and L'Her, 2006; Oswald and Young, 2004; Rau and Vermaelen, 2002; Brav et al., 2005). This is also related to the market timing hypothesis whereby corporate managers issue shares at high prices and repurchase them at low prices (Baker and Wurgler, 2002). However, unlike cash dividends or tender offer ${ }^{4}$ buybacks, open market repurchases are costless and non-committal ${ }^{5}$; they should therefore not be treated as credible signals. However, since a share

\footnotetext{
${ }^{4}$ Previous studies show that the market reacts more to the announcement of fixed price share repurchase programmes (e.g., Grullon and Ikenberry, 2000; Louis and White, 2006; Vermaelen, 1981; Peyer and Vermaelen, 2005) because the premium paid by the firm when it repurchases the tendered shares is seen as a costly signal to the market, thus bearing more credibility.

${ }^{5}$ Stephens and Weisbach (1998) show that many firms do not actually repurchase their shares after they announce an open market repurchase programme, and Lie (2005) finds no evidence that at the time of a repurchase intention announcement, investors can predict which firms will actually follow through and repurchase their shares. This is because the signal has already worked because the firm has already attracted the market's scrutiny (Bhattacharya and Dittmar 2003), and their goal of increasing their share price has already been achieved (McNally 1999).
} 
buyback attracts the market scrutiny, they can be credible signals after all (Bhattacharya and Dittmar, 2003).

Previous studies relate the negative excess returns in the pre-announcement period to a firm's undervaluation resulting from information asymmetries (e.g., in the US: Ikenberry et al., 1995; Jagannathan and Stephens, 2003; Dittmar, 2000; in the UK: Rau and Vermaelen, 2002; Lasfer, 2005; Oswald and Young, 2004; in Canada: McNally, 1999; Ikenberry et al., 2000; in Australia: Mitchell and Dharmawan, 2007; in France: Ginglinger and L'Her, 2006; and in Germany: Hacketal and Zdantchouk, 2006). We use as a proxy of undervaluation the variable (RET_lyr), which is the cumulative daily market-adjusted stock returns for the entire year prior to the announcement of a share repurchase (-261 to -2 days). ${ }^{6}$ We expect to find a negative relationship between the pre-announcement performance and the likelihood of announcing a share buyback. As an alternative proxy for undervaluation (Ikenberry et al., 1995; Ikenberry et al., 2000; Kasznik, 1999; Dittmar, 2000) and growth (Myers, 1977; Mitchell and Dharmawan, 2007), we include the market-to-book ratio (MKBK), as in Ikenberry et al. (1995), who find that that firms with low market-to-book ratios earn abnormal returns in the subsequent periods, which is in line with the undervaluation hypothesis.

Since small firms are more likely to have higher information asymmetries and more likely to be misvalued (Vermaelen, 1981), Mitchell and Dharmawan (2007) find in Australia that smaller firms experience a higher signalling impact due to the information asymmetries. Similarly, a number of US studies find that large firms are

\footnotetext{
${ }^{6} \mathrm{We}$ replicate the logit models by estimating the market-adjusted returns during smaller timeframes in order to identify if it is a longer- or a shorter-term undervaluation that can have a significant impact on the decision to announce a share repurchase and whether managers time share repurchase announcements. The smaller time periods employed are -151 to -2 days (6months), -42 to -2 days (2months), and -22 to -2 days (20 days) prior to the announcement of intention to repurchase. In all cases, the results remain unaltered.
} 
more likely to undertake share repurchases (Dittmar, 2000; Grullon and Michaely, 2002; Ikenberry et al., 1995). We expect to find that large firms, proxied by total assets $(S I Z E)^{7}$ (Dittmar, 2000; Grullon and Michaely, 2002; and Jagannathan and Stephens, 2003) are more likely to announce their intention to repurchase their shares.

Typically, share repurchases are taxed as capital gains; therefore, share repurchases can be more tax efficient and valuable for shareholders compared to cash dividends (Grullon and Michaely, 2002). However, Bagwell and Shoven (1989) and Dittmar (2000) find no evidence of taxation having an impact on payout policies. Similarly, La Porta et al. (2000) report inconclusive evidence on the impact of taxation on dividend policy (though the authors do not account for share buybacks) and Hubbard and Michaely (1997) report some tentative evidence of a tax preference between cash dividends (taxed as regular income) and stock dividends (taxed as capital gains) but without any lasting effects, contrary to the tax hypothesis. De Angelo et al. (2004) find that the clientele effect and tax considerations are not determining factors of dividend policies.

In contrast, a number of studies (e.g., Masulis, 1980; McNally, 1999; Grullon and Michaely, 2002; Lie and Lie, 1999; Rau and Vermaelen, 2002; Lasfer, 2005; Kooli and L'Her, 2010) report evidence that the differential between capital gains tax and income tax charged on cash dividends and taxation in general is an important driver of firms' payout decision making and the respective market reaction. Similarly, Desai and Jin (2011) find that rational investors (i.e., tax-sensitive institutional investors) take into account the tax considerations involving the payout method, which in turn affects the firms' decisions on which payout method to carry-out. This is consistent with Lie and Lie (1999), who find that, conditional on the proportion

\footnotetext{
${ }^{7}$ Alternatively, we replicated our models by using as a size proxy the natural logarithm of the total value of a firm's market capitalization, as in Rau and Vermaelen (2002), and our results remain unaltered.
} 
owned by institutional investors, managers are more sensitive to their shareholders' tax implications. Alzahrani and Lasfer (2012) find in countries with strong investor protection that investors prefer to receive fewer dividends when the cost of tax is high rather than reducing the agency costs via dividend payouts. In contrast, in lower investor protection countries, taxation has a minimal impact on payout policies. For capturing the potential impact of taxation on announcing share buybacks, we follow Alzahrani and Lasfer (2012) and employ the effective tax differential ratio ${ }^{8}$ (TAX) defined as the ratio of after-tax dividend to after-tax capital gains. A ratio higher than one signifies that dividends have a tax advantage over buybacks. Therefore, we can assess the potential tax advantage of dividends over capital gains. ${ }^{9}$

Given their flexibility and potential tax advantage, open market share buybacks can be viewed as substitutes to cash dividends (Grullon and Michaely, 2002; Skinner, 2008). In contrast, De Angelo et al. (2000) and Dittmar (2000) in the US and Denis and Osobov across a sample of countries (2008) find no evidence in support of the substitution hypothesis. Jagannathan et al. (2000) find that buybacks are complements rather than substitutes to dividends, in line with Jain et al. (2009) and Mitchell and Dharmawan (2007) in Australia. As in Dittmar (2000), we control for the payment of dividends with the ratio of regular cash dividends divided by the firm's net income (DIV/NI). Alternatively, we employ the dividend yield ratio (DIV_YIELD) as in McNally (1999).

\footnotetext{
${ }^{8}$ We search the OECD database along with EU, national revenue and statistics websites, and crossreferenced professional publications to identify the personal income (effective) and capital gains tax rates for each country (United Kingdom, France, and Germany).

9 Alternatively, we use a favourable capital gains differential tax dummy variable, which takes the value of one for every event occurring when taxed lower than the personal income tax, and zero otherwise. The results remain the same.
} 


\section{Data and methodology}

\subsection{Sample analysis}

The sample of repurchasing firms is constructed by identifying all the announcements of intention to repurchase ordinary shares in the open market. The data are collected by using news articles posted in Perfect Analysis and Factiva databases from the $1^{\text {st }}$ of January, 1997 through to the $31^{\text {st }}$ of December, 2006. The reason for selecting this time period is because it was not until 1998 that share repurchasing was allowed to take place more freely in both Germany and France, thus allowing us to perform the cross-country analysis across the three markets. These databases report any news announcements that were available in the press made by UK and European corporations on share repurchases. The sample is refined so as to involve solely firms that announce their intention to repurchase ordinary shares in the open market, thus excluding announcements concerning the repurchase of B-shares or preference shares. Additionally, we control the sample for American Depositary Receipts (ADRs) and cross-country listings. Moreover, financial firms, property companies, and investment trusts are excluded from the sample. Such exclusion is common practice in the literature (e.g., Shleifer and Vishny, 1997; Fama and French, 1992). Finally, corporations included in the sample are required to have their share prices listed on DataStream and their accounting data on Worldscope. The sample contains 970 announcements of intention to repurchase from corporations primarily listed in the United Kingdom (513 announcements), France (263 announcements), and Germany (194 announcements).

After collecting the sample of firms that have announced an open market share repurchase (test-sample), we proceed to the construction of the control firms sample. In order to construct the control sample of non-repurchasing firms, we collect data on 
all domestic companies that were trading in the respective main markets of each of the three countries under study that have not made a share repurchase announcement during the ten-year period from 1997 to 2006. The approach employed for matching the repurchasing firms with the non-repurchasing firms is standard in the literature. For every year in the study, we randomly generate a sample of firms from the population of firms that have not announced a share repurchase, which we refer to as the 'control' group. Each control firm is selected randomly following a uniform distribution and only once from the pool of companies that have not announced a share repurchase programme for the ten-year period under study ${ }^{10}$. Following Hasbrouck (1985), Jagannathan and Stephens (2003), and Mitchell and Dharmawan (2007), we employ an industry-matching procedure and, alternatively, a market-tobook procedure, a size-matching procedure (based on market capitalisation), and a non-matching procedure to check the robustness of the results.

The industry-, market-to-book-, and size-matching procedures are performed on a one-to-one basis; that is, for every test firm, a unique control complying with the required matching criteria is selected. ${ }^{11}$ For a robustness check, we do not match a

\footnotetext{
10 The matching method of test and control firms (i.e., repurchasing and non-repurchasing firms, respectively) is common in the literature (e.g., Hasbrouck, 1984; Jagannathan and Stephens, 2003; Mitchell and Dharmawan, 2007; etc.) since choice-based samples have higher information content (Cosslett, 1981). Since a random matching will yield substantially larger control samples compared to the test samples, rendering the estimation procedure inefficient (Palepu, 1986), the employed matching method ensures that the samples are adequately balanced and incorporate certain distinguishable firmand/or industry-specific Hasbrouck (1985) characteristics. This is consistent with Manski and Lerman (1977) and Manski and McFadden (1981) who argue that a choice-based sample will provide more efficient estimates than a random sample of the same size, while Cosslett (1981) characterizes such a sample as a close-to-optimal design. Finally, we employ a number of different model selection methods in order to ascertain the robustness of the results irrespective to the sample specification.

${ }^{11}$ For the industry-matched samples, we randomly select the control firms from the same two-digit Standard Industry Classification (SIC) code that have not announced a share repurchase programme within the whole ten-year period of this study, and we assign them with a company from the testsample that has the same two-digit industry code. For the market-to-book matching method, we randomly select a control firm that has not made a repurchase announcement within the whole ten-year period under study and that has a market-to-book ratio that falls within a ten percent range above or below the respective level of the test firm during the year of the repurchase announcement. Similarly, for the size-matched method, we randomly select a control firm that has not made a repurchase announcement within the entire ten-year period under study and that has a respective market value that
} 
repurchasing firm with a specific non-repurchasing firm. Rather, we include in the model all the firms that are trading in each respective stock exchange in each year, for the ten-year period under study. In this case, all firms that have made a share repurchase announcement appear throughout the ten-year period as repurchasing (test) firms, and the remaining firms that have never made a share repurchase announcement throughout the ten-year period are employed as non-repurchasing (control) firms.

Table 1 reports the number of repurchasing and non-repurchasing firms that met the criteria for each of the four matching procedures. It should be noted, however, that, apart from the unmatched samples, for every repurchasing firm there is an equivalent non-repurchasing firm. This means that half of the total number of firms per annum is repurchasing firms, and the other half are non-repurchasing firms for each matching procedure. ${ }^{12}$

\subsection{Methodology}

In order to determine the functional relationship between the managerial incentives and the probability of an open market share repurchase announcement taking place in a given period, a standard binary logit model is employed:

$$
p_{(i, t)}=\frac{1}{1+e^{-\beta x(i, t)}}
$$

where $p_{(i, t)}$ is the probability that firm $i$ will announce a share repurchase programme in period $t, \mathrm{x}(i, t)$ is a vector of variables with potential discriminatory ability as discussed earlier in the potential drivers section, and $\beta$ is a vector of unknown

falls within a ten percent range above or below the respective level of the test during the year of the repurchase announcement.

${ }^{12}$ Because each test firm is matched with a unique control firm that appears only once in the sample of control firms and due to the respective criteria restriction imposed on each matching method (industry, size, and market-to-book), each matching-method yields smaller test samples, relative to the initial 970 open market share repurchase announcements. 
parameters to be estimated. For classifying each firm between repurchases and nonrepurchases, the estimated probability of announcement is compared to a predetermined cut-off probability. Since an arbitrary 0.5 cut-off probability will result in inaccurate estimates and interpretation difficulties, as in Palepu (1986), we estimate the cut-off probability separately for each model based on the decision context in which the model's predictions are to be applied and the respective plots of probability distributions.

\section{Empirical evidence}

\subsection{Univariate analysis}

For both groups (repurchasing and non-repurchasing firms), we collect a list of financial variables with potential discriminatory ability, as discussed in the literature review section. The firm characteristics for each group of firms (test and control firms) and for each country are presented in Table 2; panels A and B present the firm characteristics and summary statistics for the industry, size, market-to-book, and unmatched samples. It should be noted that, for the market-to-book and size-matched methods, the differences in means (between the sample and control firms) for the respective market-to-book and size proxy variables are not reported since we control for these variables.

In the industry matched samples in all three countries, repurchasing firms have significantly higher excess cash and are larger in size compared to non-repurchasing firms, as proxied by cash flow and total assets, respectively. Moreover, it is only in Germany that firms are exploiting their excess debt cash, as shown by the significantly lower leverage ratios of the repurchasing firms - it is only in France that repurchasing firms pay higher dividends. 
When comparing firms of similar size, we find it is only in Germany and France that repurchasing firms have significantly lower dividend yields and leverage, which supports the excess debt capacity hypothesis. Finally, we find that in Germany, repurchasing firms have a significantly lower growth (captured by Tobin's q) compared to non-repurchasing firms of similar size. On the comparison of firms with similar market-to-book ratios, we find that repurchasing firms are larger in size in all three countries, and only in the UK and Germany do repurchasing firms have higher growth rates, suggesting that firms that make buyback announcements are highgrowth firms wanting to signal their undervaluation to the market. In France, we find that repurchasing firms have significantly lower levels of ownership concentration and are larger in size, suggesting that it is larger firms that tend to announce a buyback programme.

For the unmatched samples, the findings support in their majority the results derived from the previous three matching methods and are consistent with our expectations. Moreover, we find that in the UK, contrary to Germany and France, repurchasing firms pay high dividends and cater to higher tax shareholder clienteles, consistent with Alzahrani and Lasfer (2012). In sum, share repurchasing firms are more widely held, suggesting that share buybacks can serve as a self-imposed discipline mechanism for management and reduce the respective agency costs. In addition, we find some evidence for the excess cash flow and excess debt hypotheses. Finally, we find that that size, growth, and dividend yield ratios are variables that can have a discriminatory ability, which can be useful in order to determine the characteristics of firms that announce their intention to repurchase their shares. 


\subsection{Logit analysis}

In this section, we apply the same logit model for the industry-matched samples in each country and then replicate all the models for the size-matched, market-tobook-matched, and unmatched samples for a robustness check. ${ }^{13}$ Table 3 reports the results from the logit regressions, and Table 4 reports the marginal effects of each explanatory variable for each country and for the four sample matching methods. ${ }^{14}$ What is most apparent is that for all three countries and consistent with our expectations, ownership concentration and firm size have a significant impact on the decision to announce a share repurchase, suggesting that large and widely held firms are more likely to make a buyback announcement. For instance, for the industrymatched samples, a one standard deviation increase in ownership concentration reduces the likelihood of a firm making a buyback announcement by approximately $19 \%$ in the UK and Germany and an even larger reduction of approximately $24 \%$ in France, consistent with the findings of Mitchell and Dharmawan (2007) and Oswald and Young (2008). Furthermore, for the industry-matched samples, a one standard deviation change in size increases the likelihood of an open market share repurchase announcement by approximately $24 \%$ in the U.K., $15 \%$ in Germany, and $20 \%$ in France. This shows that even though size is a significant factor that influences managers' incentives for making a buyback announcement, its impact varies across countries.

In addition, we find some evidence that growth firms in France and Germany, as captured by the positive market-to-book coefficient, are more likely to make a buyback announcement. In the industry-matched samples, we find that low growth

\footnotetext{
${ }^{13}$ It should be noted that, for the size-matched samples, we exclude the SIZE proxy, whereas for the market-to-book-matched samples, we exclude the undervaluation proxy MKBK since we have already controlled for these variables in each matching method, respectively.

${ }^{14}$ The correlations between the variables are lower than 0.40 (not reported). However, in cases of pairwise correlations, auxiliary regressions are employed in order to make them orthogonal.
} 
firms with excess cash in the UK and France, as captured by the DFCF variable, are more likely to make a buyback announcement. However, for the unmatched samples, the results for the UK show the opposite, though this can be driven by the significantly different capital needs across industries. The results on the relationship between dividends and share buybacks show that, depending on the corporate culture, the motives and perceptions can be significantly different. In particular, in the UK and Germany, dividends and share buybacks seem to be complements to each other (consistent with Dittmar, 2000; Jagannathan and Stephens, 2003; Mitchell and Dharmawan, 2007), whereas in France, share buybacks substitute dividends, as shown by the negative coefficient of cash dividends consistent with Grullon and Michaely (2002) and Skinner (2008). The evidence on the tax differential impact is not strong. It is only on the unmatched samples in the UK and Germany that the tax differential has a positive and significant impact on the likelihood of a buyback announcement. This suggests that in France managers are not concerned with catering to their shareholders' tax considerations. This is consistent with Brounen et al. (2004) who find that managers are less shareholder-oriented, and it is in line with Alzahrani and Lasfer (2012), who find that the impact of tax consideration on payouts is relatively weak as opposed to strong investor countries, such as the UK.

Turning on the models' predictive ability, even though the unmatched samples have higher overall prediction ability compared to the industry-matched samples, they do not perform well on correctly predicting the repurchasing firms since the samples are dominated by non-repurchasing firms. As shown in Table 3, the industry-matched models have the highest McFadden $R^{2}$ values and the Hosmer-Lemeshow statistics for goodness-of-fit along with the respective chi-square statistics, suggesting that the industry-matched estimates fit the data at an acceptable level and they have a strong 
predictive ability. In particular, the industry-matched samples perform very well in the UK and France since they provide correct overall predictions of approximately $73 \%$ and $78 \%$, respectively. In Germany though, the models have a relatively lower predictive ability, but they still predict correctly $68 \%$ the total sample.

\subsection{Robustness of empirical findings}

For verifying which factors have a consistent impact on the decision to make a share repurchase announcement across countries, we select the industry-matched samples ${ }^{15}$ and pool them into one unified sample. The logit estimates and respective marginal effects are reported in Table 5. The results show that large and widely held firms are more likely to make a buyback announcement - consistently throughout the three countries. Furthermore, the results show that a one standard deviation increase in size significantly increases the likelihood of a repurchase announcement by approximately $30 \%$. Similarly, a one standard deviation decrease in ownership concentration leads to a significant increase in the likelihood of a buyback announcement.

However, contrary to the findings of the analysis for each country individually, we find that leverage also has a negative and significant impact on the decision to announce an open market share repurchase. In particular, a one standard deviation decrease in leverage causes a significant $50 \%$ increase in the likelihood to announce an open market share repurchase programme. This suggests that firms that have low leverage are more likely to announce a share repurchase. In addition, we find that the combination of high excess cash and low growth, captured by the dummy variable $D F C F$, has a significant impact, but only on the $10 \%$ confidence interval, and that a one standard deviation change causes $3.5 \%$ increase in the likelihood of a share

\footnotetext{
${ }^{15}$ Our selection is based on the fact that the industry-matched samples have the highest McFadden Rsquared values and additionally control for any industry-specific characteristics.
} 
repurchase programme being announced. Regarding the models' performance on predicting the likelihood of a share buyback announcement, the models perform successfully since model 1 (excluding the two country dummies) correctly identifies approximately $71 \%$ of the test firms and correctly identifies approximately $73 \%$ of both test and control firms.

For checking the forecasts' robustness, we run additional in- and out-of-sample tests, using a boot-strap simulation technique. Since the industry-matched samples yield on average the highest proportions of correct repurchase likelihood predictions, we report the results from the boot-strap simulation for the industry-matched samples. The approach on the boot-strap technique is as follows. From the overall sample of test and control firms for each country, we randomly select $85 \%$ of the firms and estimate the logit models discussed above for each country. This sample of $85 \%$ of the total sample of firms forms the basis of the simulated in-sample results. The remaining $15 \%$ of the observations are then used in order to assess how well the model performs on an out-of-sample basis, as well as for the respective calculation of Type I and Type II errors. This simulation is repeated 5,000 times, selecting a different random in-sample of $85 \%$ of the overall sample of firms each time.

The average results from the boot-strap technique for each country are reported in Table 6. Panels A, B, and C report the estimation outputs for the industry-matched samples of the UK, Germany, and France, respectively. Panel D reports the estimation outputs for the combined sample of all three countries, excluding the two country dummies (Model 1). The coefficient estimates from the boot-strap simulation are similar to the ones reported in the original logit model without any significant changes on the interpretation of the results. Further, the results for correctly identifying both a repurchasing and a non-repurchasing firm overall are similar to the ones reported in 
the original logit model and confirm that size and ownership concentration have a significant impact on share buyback announcements across all three countries, regardless of any regulatory, tax, and institutional differences.

Regarding the models' predictive ability, the boot-strap simulations display significantly higher results for correctly identifying repurchasing firms of approximately $85 \%$ in all three countries. Overall, the results show the robustness of the original logit models in predicting the likelihood of a firm announcing a share repurchase programme, and the correctly predicted likelihoods of a share buyback announcement are higher than the ones reported in Mitchell and Dharmawan (2007) and Barth and Kasznik (1999), even after checking for their robustness with a bootstrap technique.

\section{Summary and conclusions}

This paper strives to identify the main factors and financial firm characteristics that influence managers' decision to make a buyback announcement. We employ a sample of 970 buyback announcements in the UK, France, and Germany, and we find that, consistently in all three countries, large and widely held firms are more likely to announce their intention to repurchase their shares in the open market. Further, we find some evidence that buybacks are complements rather than substitutes to dividends and that it is only UK firms with low growth and excess cash that have a higher propensity to make a buyback announcement. In addition, we find some evidence in France and Germany that a firm's potential undervaluation has a significant impact on the decision to announce a share repurchase.

The contribution of this paper is the identification of the determinants that influence firms' decisions to announce their intention to repurchase their shares in the open market in a cross-country dimension, thus accounting for cultural, regulatory, 
and institutional differences among the countries under study. Hence, we identify which motives have a consistent effect on the announcement of a share repurchase in all three of the largest and most important European markets and to what extent. In addition, this study constructs and presents a model with a strong ability of predicting the likelihood of a firm making a share repurchase announcement in each of the three countries under study.

However, the findings of this research study can be applied to further research by identifying to what extent the managerial determinants for making an open market share repurchase announcement drive the market reaction to such announcements. Finally, since firms making share buyback announcements enjoy short-term (Vermaelen, 1981) and long-term positive excess returns (Ikenberry et al., 1995; Chan et al., 2010), the results of this study can potentially be employed in investment strategies and the construction of profitable portfolios. 


\section{References}

Agrawal, A.K., 2012. The impact of investor protection law on corporate policy and performance: Evidence from the blue sky laws. J. Finan. Econ. Forthcoming.

Allen, F., Michaely, R., 2003. Payout policy, North-Holland Handbooks of Economics. Constantinides G., Harris, M. and Stulz R. (eds).

Alzahrani, M., Lasfer, M., 2012. Investor protection, taxes and dividends. J. Corp. Finan. 18, $745-762$.

Amihud, Y., Li K., 2006. The Declining Information Content of Dividend Announcements and the Effects of Institutional Holdings. J. Finan. Quant. Anal. 41, 637-660.

Andriosopoulos, D., Lasfer, M., 2012. The Market Valuation of Share Repurchases in Europe: A cross-country analysis. Working Paper, Cass Business School.

Babenko, I., 2010. Share repurchases and pay-performance sensitivity of employee compensation contracts. J. Finance 64, 117-150.

Bagwell, L.S., 1991. Share repurchase and takeover deterrence. J. Economics 22, 72-88.

Bagwell, L.S., 1992. Dutch auction repurchases: an analysis of shareholder heterogeneity. J. Finance 47, 71-105.

Bagwell, L.S., Shoven, J.B., 1988. Share repurchases and acquisitions: an analysis of which firms participate. In: Auerbach, A. (Ed.), Corporate Takeovers: Causes and Consequences, 191-220.

Barth, M. E., Kasznik, R., 1999. Share Repurchases and intangible assets. J. Account. Econ. $28,211-241$.

Bartov, E., Krinsky, I., Lee, J., 1998. Evidence on how companies choose between dividends and open market stock repurchases. J. Appl. Corp. Finan. 11, 89-96.

Bartram, M., S., Brown, P., How, J., C.,Y., Verhoeven, P., 2009. Agency conflicts and corporate payout policies: A global study. Working Paper. Available at SSRN: http://papers.ssrn.com/sol3/papers.cfm?abstract_id=1068281.

Bhattacharya, U., Dittmar, A., 2003. Costless versus costly signalling: Theory and evidence from share repurchasing. Kelley School of Business Working Paper.

Brav, A., Graham, J.R., Harvey, C.R., Michaely, R., 2005. Payout policy in the 21 st century. J. Finan. Econ. 77, 483-527.

Brounen, D., De Jong, A., Koedjik, K., 2004. Corporate finance in Europe: Confronting theory with practice. J. Finan. Manage. 33, 61-101.

Chan, K., Ikenberry, D.L., Lee, I., Wang, Y., 2010. Share repurchases as a potential tool to mislead investors. J. Corp. Finan. 16, 137-158.

Comment, R., Jarrell, G.A., 1991. The relative signalling power of Dutch-auction and fixedprice self-tender offers and open-market share repurchases. J. Finance 46, 1243-1271. 
Cosslett, S.R., 1981. Efficient estimation of discrete choice models. In: Manski C.F., McFadden, D. (Eds.), Structural analysis of discrete data with econometric applications, MIT Press, Cambridge MA.

De Angelo, H., De Angelo, L., Skinner, D.J., 2000. Special dividends and the evolution of dividend signaling. J. Finan. Econ. 57, 309-354.

De Angelo, H., De Angelo, L., Skinner, D.J., 2004. Are dividends disappearing? Dividend concentration and the consolidation of earnings. J. Finan. Econ. 57, 425-456.

De Angelo, H., De Angelo, L., Stulz, R., 2006. Dividend policy and the earned/contributed capital mix: A test of the life-cycle theory. J. Finan. Econ. 81, 227-254.

De Cesari, A., Espenlaub, S., Khurshed, A., Simkovic, M., 2012. The effects of ownership and stock liquidity on the timing of repurchase transactions. J. Corp. Finan. 18, 10231050 .

Denis, D., Osobov, I., 2008. Why do firms pay dividends? International evidence on the determinants of dividend policy. J. Finan. Econ. 89, 62-82.

Desai, M.A., Jin, L., 2011. Institutional tax clienteles and payout policy. J. Finan. Econ. 100, 68-84

Dittmar, A.K., 2000. Why do firms repurchase stock? J. Business 73, 331.

Easterbrook, F.H., 1984. Two agency-cost explanations of dividends. Am. Econ. Rev. 74, 650.

Eije v., H., Megginson, W.L., 2008. Dividends and share repurchases in the European Union. J. Finan. Econ. 89, 347-374.

Espahbodi, H., Espahbodi, P. 2003, Binary choice models for corporate takeover, J. Bank. Finan. 27, 549-574.

Faccio, M., Lang, L.H.P., 2002. The ultimate ownership of Western European corporations, J. Finan. Econ. 65, 365-395.

Fama, E., French, K., 1992. The cross-section of expected stock returns. J. Finance 47, 427465.

Fenn, G. W., Liang, N., 2001. Corporate payout policy and managerial stock incentives. J. Finan. Econ. 60, 45-72.

Ginglinger, E., L'Her, 2006. Ownership structure and open market stock repurchases in France. European J. Finance 12, 77-94.

Grullon, G., Ikenberry, D.L., 2000. What do we know about stock repurchases? J. Appl. Corp. Finan. 13, 31-51.

Grullon, G., Michaely, R., 2002. Dividends, share repurchases, and the substitution hypothesis. J. Finance 57, 1649-1684.

Grullon, G., Michaely, R., 2004. The information content of share repurchase programs. J. Finance 59, 651-680. 
Grullon, G., Michaely, R., Swaminathan, B., 2002. Are dividend changes a sign of firm maturity? J. Business 75, 387-424.

Guay, W., Harford, J., 2000. The cash-flow permanence and information content of dividend increases versus repurchases. J. Finan. Econ. 57, 385-415.

Hasbrouck, J. 1985. The characteristics of takeover targets: q and other measures, J. Bank. Finan. 3, 351-362.

Hovakimian, A., Opler, T., Titman, S., 2001. The debt-equity choice. J. Finan. Quant. Anal. $36,1$.

Ikenberry, D., Lakonishok, J., Vermaelen, T., 1995. Market underreaction to open market share repurchases. J. Finan. Econ. 39, 181-208.

Ikenberry, D., Lakonishok, J., Vermaelen, T., 2000. Stock repurchases in Canada: Performance and strategic trading. J. Finance 55, 2373-2397.

Jagannathan, M., Stephens, C., 2003. Motives for multiple open-market repurchase programs. Finan. Manage. 32, 71-91.

Jagannathan, M., Stephens, C.P., Weisbach, M.S., 2000. Financial flexibility and the choice between dividends and stock repurchases. J. of Finan. Econ. 57, 355-384.

Jain, A., B., Shekhar, C., Torbey, V., 2009. Payout initiation by IPO firms: The choice between dividends and share repurchases. Quart. Rev. Econ. Finan. 49, 1275-1297.

Jain, R., 2007. Institutional and individual investor preferences for dividends and share repurchases. J. Econ. Bus. 59, 406-429.

Jensen, M.C., 1986. Agency costs of free cash flow, corporate finance, and takeovers. Am. Econ. Rev. 76, 323.

Jensen, M.C., 2004. The agency costs of overvalued equity and the current state of corporate finance. Europ. Finan. Manage. 10, 549-565.

Jensen, M.C., Meckling, W.H., 1976. Theory of the firm: managerial behaviour, agency costs and ownership structure. J. Finan. Econ. 3 (4), 305-360.

Jolls, C., 1998. The role of incentive compensation in explaining the stock-repurchase puzzle. Mimeo, Harvard Law School. Working Paper.

Kooli, M., L'Her, J.-F., 2010. Dividends versus share repurchases. Evidence from Canada: 1985-2003. Finan. Rev. 45, 57-81.

La Porta, R., Lopez-de-Silanes, F., Shleifer, A., 1999. Corporate ownership around the world, J. Finance 54, 471-517.

La Porta, R., Lopez-de-Silanes, F., Shleifer, A., and Vishny, R., 2000. Agency problems and dividend policies around the world. J. Finance 55, 1-33.

La Porta, R., Lopez-de-Silanes, F., Shleifer, A., and Vishny, R., 1997. Legal determinants of external finance, Journal of Finance 52, 1131-1150.

Lasfer, M.A. (2005) The market valuation of share repurchases in Europe. Working paper, 
Cass Business School, London.

Lie, E., Lie, H.J., 1999. The Role of Personal Taxes in Corporate Decisions: An Empirical Analysis of Share Repurchases and Dividends. J. Finan. Quant. Anal. 34, 533-552.

Louis, H., White, H., 2007. Do managers intentionally use repurchase tender offers to signal private information? Evidence from firm financial reporting behaviour. J. Finan. Econ. 85, 205-233.

Manski, C.F., Lerman, S.R., 1977. The estimation of choice probabilities from choice based samples. Econometrica 45, 1977-1988.

Manski, C.F., McFadden, D., 1981. Alternative estimators and sample designs for discrete choice analysis. In: Manski, C.F., McFadden, D., (Eds.), Structural analysis of discrete data with econometric applications, MIT Press, Cambridge MA.

Masulis R. W., 1980. Stock Repurchase by Tender Offer: An Analysis of the Causes of Common Stock Price Changes. J. Finance 35, 305-319.

McNally, W.J., 1999. Open Market Stock Repurchase Signaling. J. Finan. Manage. 28, 55-67.

McNally, W.J., Smith, B.F., 2007. Long-run returns following open market share repurchases. J. Bank. Finan. 31, 703-717.

Mitchell, J.D., Dharmawan, G.V., 2007. Incentives for on-market buy-backs: Evidence from a transparent buy-back regime. J. Corp. Finan. 13, 146-169.

Morck, R., Wolfenzon, D., Yeung, B., 2005. Corporate governance, economic entrenchment and growth. J. Econ. Lit. 43, 655-720.

Myers, S.C., 1977. Determinants of corporate borrowing. J. Finan. Econ. 5, 147-175.

Nohel, T., Tarhan, V., 1998. Share repurchases and firm performance: new evidence on the agency costs of free cash flow. J. Finan. Econ. 49, 187-222.

Opler, T., Titman, S., 1993. The Determinants of Leveraged Buyout Activity: Free Cash Flow vs. Financial Distress Costs. J. Finance 48, 1985-1999.

Oswald, D., Young, S., 2008. Share reacquisitions, surplus cash, and agency problems. J. Bank. Finan. 32, 795-806.

Palepu, K.G. 1986. Predicting takeover targets: A methodological and empirical analysis, J. Account. Econ., 8, 3-35.

Peyer, U.C., Vermaelen, T., 2005. The many facets of privately negotiated stock repurchases.

J. Finan. Econ. 75, 361-395.

Peyer, U., Vermaelen, T., 2009. The nature and persistence of buyback anomalies. Rev. Finan. Stud., 22(4):1693-1745.

Rajan R.G., Zingales, L. 1995. What Do We Know about Capital Structure? Some Evidence from International Data. J. Finance 50, 1421-1460.

Rau, P.R., Vermaelen, T., 2002. Regulation, taxes, and share repurchases in the United Kingdom. J. Business 75, 245-282. 
Shleifer A., Vishny R., 1997. A survey of corporate governance, J. Finance, 52 (2), 737-783.

Skinner, D.J. 2008. The evolving relation between earnings, dividends, and stock repurchases. J. Finan. Econ. 87, 582-609.

Stephens, C.P., Weisbach, M.S., 1998. Actual share reacquisitions in open-market repurchase programs. J. Finance 53, 313.

Stulz, R., 1988. Management control of voting rights. J. Finan. Econ. 20, 25-54.

Vermaelen, T., 1981. Common stock repurchases and market signalling. J. Finan. Econ. 9, 139-183.

Vermaelen, T., 1984. Repurchase tender offers, signalling, and managerial Incentives. J. Finan. Quant. Anal. 19, 163.

Vermaelen, T., 2005. Share Repurchases. J. Found. Trends Finan. 3, 171-268. 